\title{
The progress of science in Uzbekistan - the foundation of the third renaissance
}

\section{Muyassarzoda FAYZIEVA ${ }^{1}$ Mariya BEKIMBETOVA ${ }^{2}$}

Tashkent State University of Economics

Tashkent Institute of Finance

\begin{tabular}{l} 
ARTICLE INFO \\
\hline Article history: \\
Received July 2021 \\
Received in revised form \\
20 July 2021 \\
Accepted 15 August 2021 \\
Available online \\
15 September 2021 \\
\hline
\end{tabular}

\section{Keywords:}

the first renaissance, the second renaissance, the third renaissance, science, scientific activity, scientific research, enlightenment.

\begin{abstract}
This research paper is devoted to the issue of applying science in building the foundation of the Third Renaissance in Uzbekistan with a focus on developed science fields in Central Asia during the First and Second Renaissances. In this research, the recent legislative and scientific activities in Uzbekistan were studied and the previous work performed in the field of science in the past years was summarized as a basis for writing this paper.
\end{abstract}

2181-1415/C) 2021 in Science LLC.

This is an open access article under the Attribution 4.0 International (CC BY 4.0) license (https://creativecommons.org/licenses/by/4.0/deed.ru)

\section{O'zbekistonda ilm-fanning taraqqiyoti - uchinchi renessans poydevori}

\section{Kalit so'zlar:}

birinchi renessans,

ikkinchi renessans,

uchinchi renessans,

ilm-fan,

ilmiy faoliyat,

ilmiy tadqiqot,

ma'rifat.

\section{ANNOTATSIYA}

Ushbu maqola Birinchi va Ikkinchi Renessans davrlarida O'rta Osiyo hududida rivojlanib taraqqiy etgan ilm-fanni diqqat markazda tutgan holda O'zbekistonda Uchinchi Renessans poydevorini qurishda aynan ilm-fanga murojaat etish masalasiga bag'ishlangan. Ushbu tadqiqotda O'zbekistonda so'nggi yillarda qabul qilingan ilm-fan va ilmiy faoliyatga tegishli qonun hujjatlari o'rganildi va o'tgan yillarda amalga oshirilgan ilmfanga tegishli ishlar sarhisob qilindi.

\footnotetext{
1 Assistant of the Human Resource Management department, Tashkent State University of Economics, Tashkent, Uzbekistan.

E-mail: fayzievamuyassar87@gmail.com.

2 MBA student, Binary Graduate School, Tashkent Institute of Finance, Tashkent, Uzbekistan.

E-mail: mariya.bekim@gmail.com.
} 


\section{Прогресс науки в Узбекистане - основа третьего ренессанса}

Ключевые слова:

первый ренессанс,

второй ренессанс,

третий ренессанс,

наука, научная

деятельность,

научное исследование,

просвещение.
АННОТАЦИЯ

Данная статья посвящена вопросу применения науки в построении фундамента Третьего Ренессанса в Узбекистане с акцентом на развитие науки в период Первого и Второго Ренессансов в Центральной Азии. В данном исследовании были изучены принятые за последние годы законодательные и нормативные документы в области науки и научной деятельности в Узбекистане, а также обобщены работы, проделанные в данной сфере за предыдущие годы.

\section{INTRODUCTION}

The word of the Third Renaissance began to be spoken in the fourth quarter of 2020 and continued in Uzbekistan for several months. It is not difficult to realize here that it is time to think and implement the act of the Third Renaissance after the First and Second Renaissances in Central Asia. If we look back to history, we may see that we are a bit late to starting the Third Renaissance as there is already a five-century gap between the previous ones. The president of the Republic of Uzbekistan, Sh. Mirziyoyev, spoke about the Third Renaissance at the governmental ceremonies, thereby assuring the relevance of this topic at the government level. President Sh. Mirziyoyev pays great attention to the development of natural and fundamental sciences. Therefore, it is a huge boost to the foundation of the Third Renaissance in Uzbekistan. The First Renaissance took place in the period of the Samanid dynasty in the IXth-XIIth centuries, and the Second Renaissance in the period of the Timurid dynasty in the last quarter of the XIVth and the first quarter of the XVIth centuries.

Generally speaking, five centuries have passed since then, and we have to build a foundation for the Third Renaissance. In this research paper, we attempted to justify the view that science is the most significant pillar for building the foundation of the Third Renaissance. In recent years, there has been an increasing interest in engaging in science, especially among adults and young people. Several legislative documents have been signed in recent years aimed at progressing science and, at the same time, at supporting aspirants to create a basis for scientific activities in Uzbekistan.

Science from the Latin word scientia, means "knowledge, a knowing; expertness" [1, Online Etymology Dictionary, " $\mathrm{S}$ "]. Modern science is commonly divided into three major branches: natural science, social science, and formal science. Each of these branches comprise of various specialized, yet, overlapping scientific disciplines that often possess their own nomenclature and expertise [2]. There is no doubt that two Renaissances occurred due to the development of science in Central Asia, and at the same time, enlightenment also prospered. The progress of science and enlightenment can be linked with the spread of Islam in Central Asia.

At the initiative of Caliph Harun al-Rashid, a scientific Center-Academy ("Bayt ul-Hikma") was established in Baghdad, which brought together scholars from all Muslim countries, including Central Asian countries. Scholars from Movaraunnahr and Khorasan, such as Musa al-Khorezmi, Ahmad al-Farghani, Marwazi, Marwarudi, and Jawhari, have made a significant contribution to making the Baghdad Academy highly recognizable on a 
world scale. One of the positive aspects of the establishment of the Arab caliphate in Movaraunnahr and the spread of Islam was the forming of the Mamun Academy in Khorezm in the 10th century. The most respected figures and Hadith scholars of the Islamic world have graduated from the Mamun Academy in our country [3]. The foundation of the modern palace of science was the result of the great and universal activities of the Muslims ummah [4, P. 219]. If we learn biographies of the scholars, we identify that these great and unique scholars knew of Islam history and had Islamic knowledge. For example, "Ibn Sina memorized of the Qur'an and other several religious books under the age of ten" [4, P. 221]. The relationship between science and Islam is subject to endless debates and still stays as controversial. In the Muslim world, many believe that modern science was first developed in the Muslim world rather than Europe and Western countries, that "all the wealth of knowledge in the world has actually emanated from Muslim civilization" and what people call "the scientific method", is actually "the Islamic method" [5, Academic dictionaries and Encyclopedias]. It is clear that great and famous scholars are immortal with their works and scientific discoveries. These days, we enjoy all of the treasures of knowledge that was accumulated by these scholars and used and transmitted by our ancestors from one generation to another. These works had an impact not only on the East enlightenment, as well as on the enlightenment of the West as well.

From the article, readers can learn that the people of the East experienced the Renaissance before the Europeans, and discover the opportunities created by our government for the development of science, and learn some recommendations for reinforcement of science and scientific activities between students and other participants in the society of Uzbekistan.

The purpose of this research is to study the importance of science in the First and Second Renaissances and to offer several recommendations that affect positively the start of the foundation of the Third Renaissance in Uzbekistan.

\section{MAIN PART}

The concept of "Renaissance" is a French word and it means "rebirth". The meaning of this term is very broad: in culture, in science, in art, in education, in general, it means that, after a long period of stagnation in the life of society, the system of values will enter a new qualitative stage. The concept of "Renaissance" was used for the first time in the development period in Europe in between the XVth and XVIth centuries. But after the publication of the book "Muslim Renaissance" in 1909 by the famous Australian orientalist Adam Metz, it became clear that the Renaissance was not a European phenomenon. On the contrary, the people of the East experienced the Renaissance earlier than Europeans.

The Great Russian orientalist academician Conrad emphasized that the Renaissance begun in China in the VIIth-VIIIth centuries, it continued in India in the VIIIth century, thereafter it passed to the Islam countries in the IXth-XIIth centuries, due to the Mongol invasion it flourished again during Amir Temur and the Temurids period. According to Linda Darling, in the past, the term "renaissance" was used in connection with highcultural developments under two Middle Eastern regimes, the Buyids (945-1055) and the Timurids (1370-1506). A re-examination of the dynamics of these two developments should help to restore a sense of this region as an active partner in worldwide cultural development and of the interconnectedness of the premodern world [6, P. 56]. When the 
Renaissance shifted to Europe in the XVth century the region of Central Asia had seen two times of the Renaissance periods (IX-XII, XIV-XVI). Al-Farghani, Al-Khorezmiy, Al-Farabi, Abu Reikhan Beruniy, Abu Ali ibn Sina (Avicenna), Yusuf Khass Hajib, Mahmud alKashgari, Mahmud al-Zamakhshari, great Hadith Scholars Imam al-Bukhari, Imam atTirmidhi, Imam An-Nasaiy, mutakallims Abu Mansur al-Maturidi, Abu al-Mu'in al-Nasafi, Islamic jurist (it is called in uzbek language "fiqh") Burhanuddin al-Marginani, scholar Nizamulmulk and others have highlighted with new sciences of the whole world since IXth century. During the Second Renaissance, scholars Qazizoda Rumi, MirzoUlugbek, Jamshid al-Kashi, Ali Qushji, classical poets and thinkers Lutfi, Sakkoki, Hafiz Khorezmi, Abdurakhmon Jami, Alisher Navaiy, Zahiruddin Muhammad Babur, historians Sharaf adDin Ali Yazdi, Mirkhand, Khandamir, artists Mahmud Muzahhib, Kemaleddin Behzad, as well as many calligraphers and musicians, musicologists and architects' fame spread around the world.

As the caliphate weakened at the beginning of the 9th century, power in the region passed into the hands of the local feudal aristocracy of the Takhirids, Safarids and Samanids. The end of the Arab yoke and the revival of local independence gave a new impetus to the development of the previously frozen national culture. Having accepted and mastered some cultural layers brought to the region through the Arabic language, and using its own traditions, Central Asia became in the 9th-12th centuries one of the main centers of science and culture of the entire planet [7].

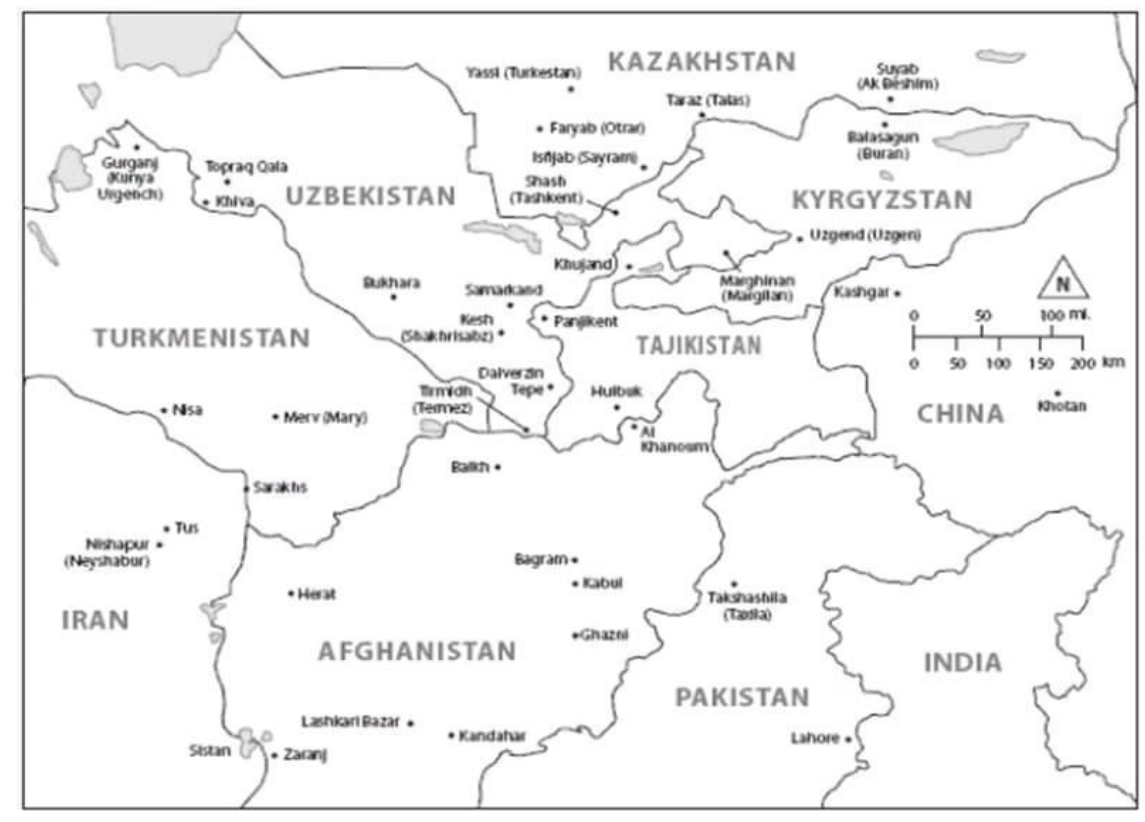

Figure 1. Some principal cities and cities of the Central Asia's Golden Age [8, P. 57].

The map which is described in Figure 1 belongs to the book "Lost Enlightenment" by Stephen Star, who is a lecturer at the School of Advanced International Studies at Johns Hopkins University and the President of the Institute for Central Asian and Caucasian Studies. According to [9] the result of Stephen Starr's efforts was a fundamental work on an amazing temporal, geographical, psychological and social space - about Central Asia, from the Arab conquest of 680-740 to the 15th century, to Tamerlane and his successors. These were the Golden Ages, a new stage in the life of the ancient Central Asian civilization. 
At the celebrations of the 29th anniversary of Independence Day of the Republic of Uzbekistan, the President of the Republic of Uzbekistan said: "In a time when the glorious power of our people is in full swing, a new awakening is being laid in Uzbekistan - the foundation for the Third Renaissance" [10]. Doubtless, the Third Renaissance will be a light example of the progress of science and economics in our country, and surely it will be a bright demonstration of all achievements accomplished with good intentions as serving the people and to please people, the intellect of our people and our young generation, of the power of talent [11].

Investments in science in recent years, the formation of the regulatory framework, and most importantly, the conditions created for scientists and freedom of creativity have defined our place in the Global Innovation Index. This can be considered as a step towards attracting investments to science and innovation in the future [11]. It can be argued that the scientific revolution has been the single greatest transformative event for humanity since the harnessing of fire. Science has cured disease, unleashed the green revolution, taken us into space, and shrunk the world through rapid transportation and instant communication [12, P. 891]. Only science can provide solutions to many of the most urgent needs of contemporary society. A conversation on how to reform science should begin now [12, P. 895].

In the past years, science and scientific activities were considered to be significant issues for the Republic of Uzbekistan. As evidence, we can refer to several legal documents related to science and scientific activity that were adopted in recent years. President Sh. Mirziyoyev signed the Law of the Republic of Uzbekistan about "On science and scientific activity" LRU-576 on 29.10.2019 [13, lex.uz]. Scientific activity is an activity aimed at the study of matter in order to determine the properties, characteristics and laws of objects, events (processes) and the application of acquired knowledge in practice, and includes fundamental and applied research. Fundamental research is theoretical and (or) experimental activity aimed at gaining new knowledge about the basic laws of the structure, formation and development of nature, society and man, studying the relationship between them, as well as objects created as a result of a certain activity. Applied research is an activity aimed at applying the results of mainly new knowledge and fundamental research to achieve practical goals and solve specific problems [13, lex.uz]. Exactly one year later from the above decree, president Sh. Mirziyoyev signed PD-6097 on 29.10.2020 the Decree of the Republic of Uzbekistan "On approval of the concept of development of science until 2030" [14, lex.uz]. This Concept is significant in terms of human capital elements in the area of science. According to this Concept the following must be implemented until 2030:

- Increase the share of total funding for science in GDP by 6 times by 2025 and 10 times by 2030;

- Increase the average age of researchers in scientific organizations to 45 by 2025 and 39 by 2030;

- Increase the share of highly qualified researchers (PhD and Doctors of Science) in the total number of researchers under the age of 39 until 2025 by 2 times, and until 2030 by 3 times;

- From January 1, 2021 a system of training and regular training of heads of scientific organizations at the Academy of Public Administration under the President of the Republic of Uzbekistan has to be introduced; 
- Implementation of the "Academic Mobility" program from January 1, 2021;

- Allocation of grants from the Talented Youth Support Fund of the Youth Academy; Giving these young people the right to freely use modern scientific equipment in scientific organizations, higher educational institutions, as well as in scientific structures under ministries, departments and organizations;

- and others.

According to the Decree of the Republic of Uzbekistan "On approval of the concept of development of science until 2030" - PhD or DSc degrees which are obtained in higher educational institutions overseas, which are in the list of the first 300 places at the international rankings are directly recognized as DSc in the Republic of Uzbekistan. As well as, The Decree of the President of the Republic of Uzbekistan "On measures to develop the spheres of education and science in a new period of development of Uzbekistan" was adopted in 2020 to improve the spheres of education, upbringing and science of the country, to boost further increase in respect for teachers and pedagogical workers, scientific and creative intelligentsia in society, development of the professional skills of students, as well as expansion of the private sector's participation in the educational system.

In addition to this, the Cabinet of Ministers of the Republic of Uzbekistan adopted several legislative documents to support the science such as the Resolution "On the procedure of paying supplements to employees in scientific, pedagogical and labor activities in all state organizations in the sphere of education and science" was adopted in 2019. This Resolution was adopted to create additional conditions for capacity building, financial incentives for the practical application of knowledge and experience of highly qualified personnel in science and education. Thereafter, the Resolution "On measures to further improve the normative and legal basis for the development of research and innovation activity" was adopted by the Cabinet of Ministers of the Republic of Uzbekistan in 2020.

The year 2020 in Uzbekistan was announced as the "Year of Science, Enlightenment and development of the Digital Economy in Uzbekistan". The mechanism for allocating targeted grant funds for fundamental and innovative research in science has also been radically revised. It is worth to recall an incident, when president Sh. Mirziyoyev was elected as a president, he first met with Uzbekistan's leader scientists and this occasion took place on 30.12.2016. This event was a new step in the development of science in Uzbekistan.

We can count a bunch of results in the field of science and scientific activities in the past years as well as at the current time in Uzbekistan. For example:

- The state order mechanism was introduced by the Ministry of Innovative Development of the Republic of Uzbekistan in 2018 to radically reform the grant financing system of fundamental, practical and innovative projects on the basis of the best international practices;

- During 2017-2020th years several scientific, educational and innovation-oriented organizations were organized. These organizations are: scientific and innovative structures-32, technoparks-8, scientific centers-8, scientific-research institutes-18, and new higher education institutions and their branches-29; 
- Mathematics, chemistry, biology and geology were established as priority areas of education and sciencein 2020. As well as, 98 specialized schools and the University of Geological Sciences were established;

- The mechanism for ensuring the professional development and training of teachers-professors in higher education and research institutions abroad was established;

- 32 new academicians were elected at the Academy of Sciences. The system for financing the activities of the Academy of Sciences from the state budget was established;

- A number of scientific-research institutes and centers have been restored;

- In the past few years, 300 billion sum funds were allocated to the institutes of the Academy of Sciences;

- The Center of Islamic Civilization of Uzbekistan has been constructing since 2017 in Tashkent. The goal of Center of Islamic Civilization of Uzbekistan is to become one of the world's leading centers of science and enlightenment. The center is intended to be a multifaceted center of science, history and activities in the various fields;

- "EL YURT UMIDI" foundation was established in 2018 and the purpose of the establishment of this foundation is to develop sustain close cooperation with Uzbek scientists, specialists and talented young people living and working abroad with great scientific potential, training and advanced training of highly qualified specialists in leading foreign educational institutions and in Uzbekistan's higher educational institutions;

- During the year 2019-2020 about 1000 scientific events were conducted in Uzbekistan, they include international events and republican events;

- "Scopus Award" ceremonies are held regularly by the Ministry of Higher and Secondary Specialized education of the Republic of Uzbekistan and Elsevier Company. At the awarding ceremony, academicians, researchers, higher educational institutions, and scientific journals are awarded;

- The website of the Ministry of Higher and Secondary Specialized Education has been launched www.moziy.edu.uz to cover the activities of our classical scientists in the territory of our country;

- Over 100 masters have been being prepared by the Academy of Sciences annually;

- In previous years, scientists of the Academy of Sciences have created more than 100 new textbooks and manuals for Uzbekistan's education system on basic educational sciences;

- A number of joint scientific projects have been increased by professionals of the Academy of Sciences and higher educational institutes for recent years;

- The Council of Young Scientists of the Academy of Sciences works actively. The Council of Young Scientists conducts competitions on best projects, examines existing problems, and implements measures to solve them;

- In the period of last years the number of women scientists increased, especially in the areas of complex sciences in Uzbekistan. The Ministry of Innovative Development of the Republic of Uzbekistan has taken the initiative to support women scientists. As a first gesture in carrying this initiative, the Ministry of Innovative Development of the Republic of Uzbekistan announced the competition of projects "Grants for women scientists" in 2020. The main purposes of this competition is attracting women to science in our republic, supporting their ideas and overall development of women who are engaged in science-education and scientific activities in various sectors and areas of the economy, as well as creation of science-intensive products and innovative technologies. 
The president Sh. Mirziyoyev addressed the parliament of Uzbekistan - Oliy Majlis at the end of 2020 and spoke on radical reforms of the six directions which must be implemented in 2021. One of these directions is science and innovation to create the foundation for the country's development. According to this direction [15] next year, the number of doctoral students at universities and research organizations will reach 4.5 thousand, which is thrice the figures in 2017. An additional 240 billion sums will be allocated from the budget for these purposes. Based on the best international experience, the scientific councils of the leading universities of the republic will be delegated the authority to confer the academic titles of associate professor and professor, academic degrees of Doctor of Philosophy and Doctor of Science. The Ahmad Fergani International Scientific Olympiad in Physics will be organized. Additional measures will also be taken to expand the scale and improve the quality of research in the field of physics, and create the necessary conditions for young scientists.

Our future plan is to engage in science in the field of human resources management. Through this paper, we intend to encounter the vast world of science and today, we already started to construct the foundation of this life-long science building process. On this path, we faced several problems as well as gathered some experience and today based on this past experience we have several proposes. Our suggestions are related to higher educational institutions and public administration organizations in Uzbekistan. They include:

- to support of bachelor and master students in the participation in international scientific conferences;

- to be active in publishing issues of bachelor and master students' (who are active in scientific research) scientific research papers in journals which are given on the list of the Higher Attestation Commission of the Republic of Uzbekistan;

- intensification of work direct to activities in scientific activities and scientific research between bachelors and masters;

- prevention of commercialization of republican and international conferences which are conducted by higher educational institutions in Uzbekistan;

- to teach the scientific language of science at the 1st year of PhD level and establish cooperation with foreign higher educational institutions with regard to PhD programs;

- to give information about science, scientific research, results of research, researchers, scientists, academicians, and their scientific activities via mass media for all participants in society;

- formation of a positive attitude of leaders/executives of organizations/entities in the field of science and research.

\section{CONCLUSION}

This conclusion supports the fact that the progress of every country and society is linked with the development of science. Attention to science and education is so vital that it will determine the future of each country. Science is the light of the mind. It encourages people to feel their existence, to understand the spiritual and material world, and to shape their thinking. Science is the light of life. Science brings happiness to people's lives and removes their focus from ignorance. History gives strong evidence for this and no one can refuse it. Based on the previous talks, we can say that there are all conditions for education in our country for those who want to study. We have to always remember that we are a 
generation of great scholars who lived and lighted the world with science in the First and Second Renaissances. The main sources of our religion The Qur'an and the Hadith emphasize that science and scholars are of the highest status. We believe that science is pivotal to laying a path for the formation of the foundation of the Third Renaissance in Uzbekistan.

\section{REFERENCES:}

1. Harper, D.: Online Etymology Dictionary, retrieved September 20, 2014.

2. "Scientific Method: Relationships Among Scientific Paradigms", Seed Magazine, March 7, 2007, Archived from the original on November 1, 2016, Retrieved November 4, 2016.

3. IX-XII-asrlarda yashab ijod qilgan O'rta Osiyolik buyuk allomalar va ularning jahon tsivilizatsiyasi rivojiga qo'shgan hissalari, http://xorazmiy.uz/oz/pages/view/254.

4. Muhammad Yusuf, M.S. (2011). Hadis va Hayot, 3-JUZ, Niyat, ixlos, ilm kitobi, "Sharq" 2011. - B. 240.

5. Academic dictionaries and Encyclopedias, Islam and science. (2017).

6. Egyptian Muslim geologist Zaghloul El Naggar quoted in [http://discovermagazine.com/ 2007/jul/science-andislam Science and Islam in Conflict] Discover magazine 06.21.2007.

7. https://en-academic.com/dic.nsf/enwiki/4017174.

8. Darling L.T. (2007). The Renaissance and the Middle East, (Guido Ruggiero / A companion to the worlds of renaissance), Blackwell Publishing, 2007.

9. Xodjaev A. (2018). Эпоха Ренессанса в духовной истории Узбекистана, https://nuz.uz/kolumnisty/33953-epoha-renessansa-v-duhovnoy-istorii-uzbekistana.html.

10. Starr S.F. (2013). Lost enlightenment: Central Asia's golden age from the Arab conquest to Tamerlane, Princeton University Press.

11. Стахов Д. Мусульманский ренессанс, Взлет и падение средневековой исламской культуры, https://gorky.media/reviews/musulmanskij-renessans/.

12. Abdullaeva O. (2020). "Ўзбекистонда янги уйғониш - учинчи Ренессанс", https://uza.uz/uz/posts/-zbekistonda-yangi-uy-onish-uchinchi-renessans-03-09-2020

13. Abdurahmonov I. (2020). Учинчи ренессанс - илм-фан тараққиёти, https://mininnovation.uz/uz/news/2334.

14. Casadevall A., Fang F.C. (2012). Reforming Science: Methodological and Cultural Reforms, Infection and Immunity, March, 2012, Volume 80, Number 3. - PP. 891-896, https://iai.asm.org/, DOI: 10.1128/IAI.06183-11.

15. Law of the Republic of Uzbekistan "On science and scientific activity" LRU-576 on 29.10.2019, https://lex.uz/uz/docs/4825305

16. Ўзбекистон Республикаси Президентининг 29.10.2020 йилдаги ПФ-6097сонли Фармони, “Илм-фанни 2030 йилгача ривожлантириш концепциясини тасдиқлаш тўғрисида", https://lex.uz/docs/5073447.

17. President Shavkat Mirziyoyev's Address to the Oliy Majlis, https://president.uz/ en/lists/view/4057. 